\title{
Editor's Note: Revaluing the Score: Archival Futurity
}

This issue of $D R J$ evidences a general thematic coherence around what I am calling archival futurity. With subject matter ranging from the fifteenth century dance manual to choreographic experiments of recent years, our authors reflect on the complex temporalities and methodologies emerging from dances that think through alternatives to conventional reconstruction. Such rethinking is not a rejection of reconstruction as a discipline per se, but a reframing of reconstruction that pivots on a radical reconsideration of the score: what the score actually is, and what can be done with it. This new attention to the score, understood as notation and/or film, but also as citation, oral transmission, text, and choreographic thought, leads to the creation of new work.

Martin Nachbar, a dancer and choreographer based in Berlin, reflects on memory and transmission. In "Training Remembering," Nachbar relates his redoing of Dore Hoyer's solo cycle Affectos Humanos (1962) to practices of touch and healing. ${ }^{1}$ In his discussion of the development of Urheben/Aufheben (2008), Nachbar articulates issues of the transmission of dances with other spheres of life practices-including medicine and architecture-to theorize the question of how the recovery of past movement, long referred to in general terms as reconstruction, actually takes place. Maaike Bleeker shows in her essay "(Un)Covering Artistic Thought Unfolding"-a response to and an exegesis of Nachbar's essay and production-that the tendency within re-enactment to avoid impersonation of an earlier artist is grounded in a decision to differentiate between who thinks and what is thought. Bleeker works through this important and illuminating insight with reference to Robert Collingwood's Philosophy of History.

If the first two articles launch into a re-evaluation and re-valuation of the score as the ontological basis of the work's having existed and continuing to exist, Seeta Chaganti returns us to an early stage of dance scoring in her "Proleptic Steps: Rethinking Historical Period in the Fifteenth-Century Dance Manual." Starting off by questioning how periodization is conceptualized in the context of basse danse and bassadanza notation, Chaganti goes on to discuss structures of anticipation and retrospection within the dance itself as well as in its textual traces. In the question of whether these archival records and the dances to which they refer belong to the premodern or the early modern, Chaganti develops a complex and fascinating meditation on prolepsis and futurity.

Isabelle Launay, in "Citational Poetics in Dance: ... of a faun (fragments) by the Albrecht Knust Quartet, Before-After 2000," chronicles efforts to rethink Vaslav Nijinsky's Afternoon of a Faun outside of the oral tradition. Launay introduces the distinction between oral transmission and citation as ways of dealing with past work, and indeed speaks of this process as an indispensable aspect of choreographic renewal. In her treatment of the return to Nijinsky in contemporary dance, she stresses the importance of generational difference, identity (not here of the work per se but of the dancer), and, at an implied level, psychoanalysis, which are all operative. The notion of citationality she develops from the literary theory of intertextuality leads her to a notion of intercorporeality with which to articulate a different sensibility for historicity. 
Selby Lynn Schwartz also raises the question of citationality with respect to gender, identity, and the score in "Bad Language: Transpositions in Mark Morris' Dido and Aeneas." Indeed, she raises it to the level of a critical methodology in her exegesis of Morris's Dido and Aeneas, where the verbal score of the opera that accompanies the dance is seen to be instrumental in the complex play of identities that are of crucial importance to the structure and import of Morris's choreography. In what is likely to become a seminal analysis of this work, Schwartz leads us through the labyrinthine processes of indexical gesture with both a learned and a literal subtext.

Starting in 2013, DRJ will move to three issues a year (April, August, and December). This will allow us to publish fifty percent more material each year. We look forward to publishing more dance scholarship more frequently.

Mark Franko

Editor, Dance Research Journal

\section{Note}

1. The German version of this essay first appeared in $\operatorname{tanz}$ (December 2011). We are grateful to Arnd Wesemann for permission to publish the essay in English. 